\title{
Downtown Nellmapius: The Vacant Plot Patient
}

\begin{abstract}
I dream that we live in a house where the front exterior consists of glass windows that run almost all the way around the dwelling. There is a great gorge that separates us from the range of mountains. A short distance away from the house on the other side of the gorge is a small volcano. Someone once built a big square black chimney around the summit. As I stare across the way, I see a pink haze forming to the right of the chimney, it has a dark lining. I hear a rumbling sound and the great windows start to vibrate. I rush forward. I see a glowing furnace building up on the inside of the mountain. The entire peak is a great, burning, hot coal. There is a huge wall of fire between myself and the mountain. Massive molten rocks explode from the chimney. There is an earthshaking blast, I am flung forward, through the glass, over the turf and then down, down, down...into the gorge. I wake up when I hit the bottom, or rather the cold stone floor. In a somnambulistic state I have stumbled down a flight of stairs.
\end{abstract}

I am in such pain that I feel as if I have fallen from a twostorey building. My leg has been very badly injured. After a week the skin breaks open on my knee, and I suffer from a great running sore on my leg. The abscess becomes worse every day. I consult one doctor after another over the next couple of months. The last physician I see pronounces a diagnosis of doom over my life. "I will have to amputate... above the knee," he muses, poking the soft flesh above the swelling. He runs his fingers through his dark, woolly hair. He has a lazy eye, and he wears a grey uniform like that of an inmate at a psychiatric hospital. I see a receptacle of instruments on his table: saws, grips, screws, knives, needles... I slide down from the high bed in a daze and leave the room.

I am governed by desperation, trauma and confusion, and feel myself slipping into a deeply disturbed mental state. Something, however, is trying to come to my rescue. I keep sensing that there is a strange power attempting to connect with me: it's an impelling force, at once all-embracing and empathic. I know where it comes from. Dr Bronkhorst, the herbalist and his patrons, those enigmatic figures I have reflected on since my childhood days are connecting telepathically. Dr Bronkhorst is a successful man in the field of unconventional treatment. I know that herbalists are famous for their miraculous healing powers. They are able to treat and cure any disorder known to man, so it's not unusual for many people to frequent them. The healing powers of herbs are able to intervene on a physical, emotional, mental and spiritual level. Sometimes when they influence your mind you can see through yourself as if you were a glass globule, and gain great insights into yourself. You may have the sense that you are elevated above yourself; can view yourself from an aerial position, and be directed to perform supernaturally well, whether you are singing, writing, dancing, or communing. Herbs even work across time, space and infinity, and so do the practitioners who use them. Some practitioners can materialize and dematerialize anywhere on earth, at will.

Clients as far away as South-West Africa, the Congo, and Cape Town visited the Dr Bronkhorst. Many of them were extremely overweight. They often remained on a vacant plot of ground near his house day and night, for weeks on end, and some lay spread out across car seats their friends or spouses removed from their vehicles so they could lie on them during the day. At night they put back the seats and all slept in the car. The others in the pale nightdresses with impassive, big, full, purpleveined faces and bloodshot eyes sat on the paraffin tins for want of something better. I remember one woman in particular in a large see-through nightdress, her mouth's big blue lips were loose and shapeless. I felt we could be friends.

When it was someone's turn to see Dr Bronkhorst, the incapacitated person would be carried by four to six bearers on a simple contrivance consisting of a wide strip of canvas nailed to two strong poles. The porters, bent double under the load, would look up and down the deserted road and move across it hastily. Once on the other side they would break through a wall of densely planted yellow trees, agitating a barrier of thick leaves that would close behind them and obscure them from 
view. As children we would wander past the herbalist's patients and my friend Ninkie, with her mouth full of bright pink toffees, would pull a face at the patrons. When the Nellmapius noonday train passed by with its one hundred coaches, and a thousand flying train wheels, she would bend down, lift her dress and show the patients her brooks!

I continue to think back on my childhood, and Dr L J Bronkhorst. Even then, I always had a connection with the doctor and his patients. I would think about them more than I should have. Sometimes I drew 'veins' upon my face with a red pen and dressed up in a large nightdress belonging to my grandmother. I would then move from mirror to mirror surveying myself in the glass.

$$
* * *
$$

I will have to go back to my home town to see Dr Bronkhorst, I decide. We plan the trip and take the long road back to Violet Park. After the long journey to the Eastern Cape, we drive over the last hill, and I see Violet Park. It is still spinning in its haze of heat and shimmer, perched on a koppie with its layered and chequered white houses running across the long, sweeping slopes. The town is still, ordered, neat and green-something of an oasis in the bleak and dry Karoo environment. Situated at the top of the town was the local GP in his sterile white consulting rooms, and in downtown Nellmapius was Dr Bronkhorst.

Although it's a small place, we drive around for an hour looking for downtown Nellmapius. My leg starts to suppurate again, blood seeps through the dressing, and a dull roaring sound starts up in my head.

'I will ask that man over there for directions, Frederik,' I suggest, pointing to an untidy figure shuffling down the road.

'Meneer... meneer, where can we find Dr Bronkhorst?'

He does not answer. Instead he puts his head down and moves away from us, increasing his pace as he goes. A woman's warm laughter, gay and taunting, echoes from a spot above us. I can sense her dark brown tresses, and the cotton ribbons she has knotted into her perfumed hair, falling halfway down the balcony in waves. We turn a corner.

'Oh, at last, Frederik, look-there is the vacant plot,' I cry. 'The sheer, dainty, cream-coloured flowers, are called the Vroue Kappie Fraai. The wind always blows them in a westerly direction, and that is why the trees also lean to one side. The patients you see resting among the Vroue Kappie Fraai are all lining up to consult Dr Bronkhorst. The skinny, tanned man with wrinkly knees carrying around a blikkan, offers people a drink of some sort and they pay him for it. I have always wondered what is in the mug he is holding.'

'What are you talking about? All I see is a cemetery with its ancient grave-stones, marble angels and Madonna and child. I don't see any people!'

'Oh, I've told you hundreds of times about this place. The Nellmapius noonday train also passes this way every day.'
As always there is very little accommodation in the town, so we have to camp at a caravan site. The second person we encounter in Violet Park is the caravan park owner. She is a thin woman with untidy grey hair, and a blind left eye. She wears a tight, short overall and a pair of long striped socks that don't match. I immediately start to question her about Dr Bronkhorst. Frederik stirs uneasily at my side.

'... No, I have been here years, but I have never heard of Dr Bronkhorst,' she says cagily. 'I don't know any sick people on a vacant plot. If there is such a site in town I would know about it. Look, I don't listen to rumours, I don't belief in ghost stories, and I don't skinner,' she hisses, putting her face close to mine.

After moving into the tent, I become extremely ill. My temperature is very high and my leg throbs unbearably. My husband sits by my side with his head in his hands. The dark hair that pours through his fingers is touched by a yellow glow from the lamplight. Such dejection I cannot bear. Time and space become disarranged, and I no longer know where I am.

It is between sleeping and waking that I spot the heavy vacant plot patient. She is seated in one of the deckchairs in our tent. I recognize her immediately. I know the face, the pale eyes, the hair. She stares at me with her flat gaze, but there is something different about her as she sits there. She appears slimmer and younger, her skin smooth and healthy. She looks serene and benevolent. I stare at the apparition for a long time and wonder how it came about that she had improved so significantly after seeing Dr Bronkhorst, but nevertheless, died so soon after her treatment. She holds out her hand to me, and I follow her out of the tent. We move down the footpath and through the khakibos until we come to the field containing the discarded phials behind Dr Bronkhorst's house where Ninkie and I played as children. Half-submerged in an old archeological site near the Bronkhorst family cemetery, where rough veld flowers grew wild and irrepressible, corks and abandoned bottles from Dr Bronkhorst's apothecary lay glittering. It was the place we loved best. With our faces grimy and our pinafores full of dirt we'd pour sand into the phials and take them home to our dolls.

Beneath a white Karoo moon, large grains of sand shine fitfully. Suffused in a silver haze, the figure in front of me glides forward smoothly, and I follow.

With nostalgia and awe, I approach the house hidden behind the high walls. I am animated, I rush forward ecstatically: I am finally going to see what lies behind them. I cannot contain my excitement. I rush through the immense stone gates, dragged apart by two people holding ropes. It is then that I see a massive, solid structure. It is as solid as a fort. On one side of the house stands an old ox-wagon, and in the front is a post to which horses were once tethered many years ago. There are several people in the waiting room and on the verandah, so I sit outside under an old 
tree among at least ten other patients. I am struck by their dress. Without exception, they are all clothed like people from a different epoch. I am reminded of old yellowed photographs of veterans returning from the First World War... the strange, unfamiliar, facial features of people of yesteryear-their unusual postures and peculiar attires. I recognize some of them! Those who know me lift their hats respectfully, and nod as I take a seat.

I have almost forgotten how I had imagined the interior as a child, but there it is: just as I had pictured it. Breathlessly I take a step forward. Soundlessly, rapturously, I move down the passage. The ancient man has just exited from a room where a sheet of light with a hint of purple shines. 'Dr Bronkhorst... Dr Bronkhorst....' He turns slowly, the light of recognition strong in his eyes, eyes that are moist and luminous, bright and perspicacious. Dignified and upright, he stands in the dim corridor holding a bottle to which a crude and irregular label is attached. Yes, the handwriting on it is refined and cultured; and yes, there is the smell of cinnabar and peppermint in the air.

He chooses the bottle from the shelf and I take it from him. I drink it, dab it onto myself and work it into my body. Increasingly a strange euphoria rises up within me; an ecstasy that lifts me up higher and higher until I soar. It starts somewhere in my abdomen, it is like a great breath of oxygen filling me from within, suffusing my whole being, expanding across time and space until I feel rarefied, on fire-I become as a moving pillar of light. I lift my arms and stretch my hands out to the doctor. A great current flows through him, electrifying me to greater heights.

I am back in the tent, resting peacefully. I awake the following morning. I experience wholeness, wellness and strange weightlessness. I remember the previous night Wonderingly I muse... did I dream, or did I really go somewhere? The joy and excitement, was it all real? Did the great healing really take place as I imagined? I revel in the glow of my perfect sense of vitality and energy.

'Look, Frederik... look,' I cry, shaking him until he wakes up. He sits up in alarm. I point to the place where the great abscess was.

'You have been missing for almost two days.' he cries hoarsely. 'Where have you been, and what's happened?' He stares at my knee incredulously, as he swings his legs over the end of the bed. Wonderingly he strokes his fingers over the spot where the abscess was.

'Unbelievable, totally unbelievable...you don't even look like the same person.'
'It's all weird... just weird.'

What happened to me is a mystery. What if I return to the doctor's rooms, where it all started? There would be some evidence, an indication that something happened, that someone visited the spot. I hurry back to the site behind the Bronkhorst house. I run, skip, leap and dash through the coarse sand and dry shrubs to seek the proof that will substantiate the events of the previous night. Yes, there lying scattered in the dusty soil and rough flowers are the discarded bottles, the broken statue bearing the likeness of Dr Bronkhorst, and my tracks in the sand. A small, empty phial lies on the ground... a drop of its viscous liquid has left a tiny, damp splat in the loose sand. I recognize the bottle as the one the doctor handed me the previous night.

The family cemetery is located close to the spot where I stand. There is an old grave two metres away. The following is inscribed on the marble plaque: 'Here lies Dr L J Bronkhorst, 1900 - 1970'-and we're living in the 1990s! There is a thud in my chest, my heartbeat becomes irregular, and I feel the blood drain from my head. I rush down to the herbalist's old house, stumbling wildly across the rough terrain towards the railway line. The great stone gates stand open; the house has been unoccupied for years, and is totally derelict. The walls are either cracked or flattened, the windows broken, the roof fallen in, the garden overgrown.... From the back of the house a dilapidated figure emerges. We meet at the railway line. I recognise him. He carries an old blikkan in his hand. He stops, turns his head in my direction, lowers the can and stares at me with hostility. Something is wrong, terribly wrong.

'Meneer... nothing looks the same today... Meneer, Dr Bronkhorst... what of Dr Bronkhorst?'

'You were here yesterday, so you won't need him anymore,' he says guardedly, looking down at my knee. I am unable to move; my feet feel as if they are sunk up to my ankles in heavy, scorching sand, hot and dry as the loose grit where the rough flowers rock among the phials in the Bronkhorst burial ground. I try to shift my feet, but they seem fixed under the railway line. A muscle in my shoulder cramps and my skin feels taut. My open mouth is a hole in a white face and the gasp of an unexpected gust of wind lifts my thin hair. A frantic sense of disarranged time and place causes a peculiar slurping sound, like with the emptying and filling up of a reservoir, to start up in my head. I stare at the blikkan man unseeingly, then lift my eyes to focus on the void that lies beyond the graves, beyond the ruin, beyond the citronyellow coloured leaves of the yellow-barked trees... . I hear the rushing wheels of the Nellmapius Noon as it approaches from a distance. It plunges forward from afar, lurching, rattling and swiftly-moving along the dangerously-winding rail road line. 